Турчин Л.Я. - Правові засади формування статутного капіталу господарських...

Регіональна конференція «Тенденції та пріоритети забезпечення ефективного розвитку суб'сктів господарювання в умовах ринкових відносин».

Полтавський інститут економіки і права, кафедра управління та адміністрування

(м. Полтава, вул. Монастирська, 6)

19 грудня 2019 року

\title{
ПРАВОВІ ЗАСАДИ ФОРМУВАННЯ СТАТУТНОГО КАПІТАЛУ ГОСПОДАРСЬКИХ ТОВАРИСТВ МАЙНОВИМИ ПРАВАМИ ІНТЕЛЕКТУАЛЬНОӤ ВЛАСНОСТІ Тези
}

\begin{abstract}
ТУРЧИН Лілія Ярославівна - аспірантка кафедри цивільного права та процесу юридичного факультету Львівського національного університету імені Івана Франка
\end{abstract}

DOI:10.32782/EP.2020.1.29

У тезах проаналізовані норми украӥнського законодавства в контексті бормування статутного капіталу господарсъких товариств майновими правами інтелектуальной власності. Висловлено позицію про критерії майнових прав інтелектуальної власності як внесків до статутного капіталу господарсъких товариств. Зокрема, до таких критеріїв віднесено оборотоздатність відповідних прав та можливість здійснення їх грошової очінки.

Ключові слова: господарсъкі товариства, статутний капітал, майнові права інтелектуальноӥ власності.

Метою створення господарських товариств є ї участь у цивільному обороті. Оскільки такий має здебільшого майновий характер, то й важливе значення має те, яким майном володіють господарські товариства. Так, основним джерелом утворення майна господарських товариств $є$ статутний капітал.

При цьому, статутний капітал не є реально існуючим, а лише становить процентне чи числове вираження реальної вартості активів товариства, відображеної в бухгалтерському обліку ${ }^{1}$. Здебільшого, науковці виділяють три функції статутного капіталу: стартову, гарантійну, функцію визначення частки кожного учасника в товаристві.

\footnotetext{
${ }^{1}$ Спасибо-Фатєєва I. В. Корпоративне управління. Право, 2007. 500 с.
}

Стартова функція полягає у тому, що статутний капітал $\varepsilon$ першоджерелом формування майна товариства і потрібен для того, щоб почати його діяльність. Зокрема, формування статутного капіталу створює юридичні та економічні передумови для участі господарського товариства в цивільному обороті, що своєю чергою визначає господарське товариство як самостійний суб'єкт цивільних правовідносин. Після створення товариства об'єкти внеску використовуються для потреб товариства. Статутний капітал відображає закріплену в статуті товариства наявність матеріальної бази для ведення учасниками власної (незалежної) підприємницької діяльності, що дає поштовх для подальшої діяльності товариства².

Статутний капітал розподіляється на частки (функція визначення частки кожного учасника в товаристві) і визначає участь кожного учасника залежно від розміру частки. Так, згідно зі статтею 167 Господарського кодексу України корпоративні права належать учасникам товариства відповідно до їхньої частки у статутному капіталі, що свідчить про безпосередній зв'язок статутного капіталу з корпоративними правами.

Гарантійна функція полягає у тому, що статутний капітал господарського товари-

2 Кашанина Т. В. Корпоративное право (Право хозяйственных товариществ и обществ). Москва: НОРМА-Инфра-М, 1999. 802 с. 
ства є гарантією захисту інтересів кредиторів і учасників. Зокрема, розмір статутного капіталу, його розподіл між учасниками господарського товариства, об'єкт внесків тощо дозволяє оцінити межі відповідальності учасників такого товариства а, відповідно, й передбачити можливі ризики для потенційних кредиторів.

Відповідно до українського законодавства вимоги щодо мінімального розміру статутного капіталу передбачені лише щодо акціонерних товариств. Відповідно до частини 1 статті 14 Закону України «Про акціонерні товариства» мінімальний розмір статутного капіталу акціонерного товариства становить 1250 мінімальних заробітних плат виходячи із ставки мінімальної заробітної плати, що діє на момент створення (реєстрації) акціонерного товариства. У цій же ж статті зазначається, що статутний капітал товариства визначає мінімальний розмір майна товариства, який гарантує інтереси його кредитоpiв.

Додержання гарантійної функції статутного капіталу мають на меті й інші норми українського законодавства. Так, згідно 3 положеннями частин 3 та 4 статті 19 Закону України «Про товариства 3 обмеженою та додатковою відповідальністю» після прийняття рішення про зменшення статутного капіталу товариства його виконавчий орган протягом 10 днів має письмово повідомити кожного кредитора, вимоги якого до товариства не забезпечені заставою, гарантією чи порукою, про таке рішення. Кредитори протягом 30 днів після отримання такого повідомлення можуть звернутися до товариства 3 письмовою вимогою про здійснення протягом 30 днів одного з таких заходів за вибором товариства: забезпечення виконання зобов'язань шляхом укладення договору забезпечення; дострокове припинення або виконання зобов'язань перед кредитором; укладення іншого договору 3 кредитором. У разі невиконання товариством зазначеної вимоги у встановлений строк, кредитори мають право вимагати в судовому порядку дострокового припинення або виконання зобов'язань перед ним.

Відповідно до положень частини 2 статті 115 Цивільного кодексу України внеском до статутного капіталу господарського товариства можуть бути гроші, цінні папери, інші речі або майнові чи інші відчужувані права, що мають грошову оцінку, якщо інше не встановлено законом. Таким чином, цивільне законодавство передбачає можливість використання нематеріальних активів, при формуванні статутного капіталу господарських товариств. Відповідно до положень Цивільного кодексу України майнові права інтелектуальної власності можуть бути внеском до статутного капіталу юридичної особи.

На нашу думку, майнові права інтелектуальної власності як внески до статутного капіталу повинні відповідати таким критеріям, як можливість здійснення грошової оцінки такого внеску та оборотоздатність (можливість вчиняти 3 ним правові дії на користь товариства).

Критерій оборотоздатності передбачає, що в разі внесення до статутного капіталу майнових прав інтелектуальної власності такі мають бути об'єктом обороту і тільки в такому випадку можуть вноситись до статутного капіталу і становити актив товариства.

Оцінка майнових прав інтелектуальної власності має важливе значення для забезпечення функцій статутного капіталу. Зокрема, у випадку неналежної оцінки відповідного внеску (оцінення внеску вище, аніж його ринкова вартість), статутному капіталу як бухгалтерському запису на стороні пасивів, відповідатимуть на стороні активів внески нижчої вартості, що порушуватиме інтереси як самого товариства, так і його учасників та кредиторів.

Відповідно до положень статті 13 Закону України «Про господарські товариства» грошова оцінка внеску учасника господарського товариства здійснюється за згодою учасників товариства, а у випадках, встановлених законом, вона підлягає незалежній експертній оцінці. Водночас, щодо акціонерних товариств, то у разі внесення майнових прав інтелектуальної власності до статутного капіталу таких, оцінка таких внесків обов'язково здійснюється суб'єктом оціночної діяльності. 